\title{
Variation of Precipitation Gradient in Mountain Areas Based on the Example of the Western Beskids in the Polish Carpathians
}

\author{
Janusz Kozak¹, Dominik Cebulak², Tomasz Stec², Andrzej Jaguśs ${ }^{1 *}$ \\ 1 University of Bielsko-Biala, Willowa 2, 43-309 Bielsko-Biała, Poland \\ 2 Graduate of the University of Bielsko-Biala, Poland \\ * Corresponding author's e-mail: ajagus@ath.bielsko.pl
}

\begin{abstract}
The study aims at investigating the so-called precipitation gradient, i.e. changes in the amount of precipitation depending on the elevation above sea level in the mountainous areas of southern Poland. The gradient value is specified in mm of precipitation per $100 \mathrm{~m}$ elevation difference. Experimental studies were conducted in two small Beskids valleys, the Barbara stream valley and the Wilkówka stream valley. Five rain gauges were installed across land elevation profiles of said valleys. Decade precipitation amounts during the summer and autumn of 2015 were recorded. The precipitation data of the national environmental monitoring from the nearby mountain and foothill weather stations from 2014-2018 were also used for the analyses. The data analyses demonstrated a large spatial variation in the amount of precipitation. The occurrence of a varied gradient, and even inverse situations i.e. greater precipitation at the locations with lower elevation, were recorded. The precipitation gradient was differentiated, particularly by the terrain exposition relative to the dominant inflow direction of moist air masses, as well as the spatial arrangement of mountain ranges.
\end{abstract}

Keywords: mountain areas, amount of precipitation, precipitation gradient

\section{INTRODUCTION}

Mountainous areas are characteristic for the occurrence of vertical variability of many environmental parameters, which is associated with changes in the elevation above sea level. The study undertaken was aimed at investigating that problem in relation to atmospheric precipitation and determining the value of the precipitation gradient. This universal parameter provides the information on the change in the amount of precipitation (in $\mathrm{mm}$ ) per every $100 \mathrm{~m}$ difference in elevation; as a rule, the amount of precipitation increases with the elevation, but this relationship is very often disturbed (Barry and Chorley 2003, Hebda-Małocha 2007, Houze 2012).

Researchers around the world are faced with the problem of determining the precipitation gradient. For example, in tropical areas, the gradient is differentiated by specific monsoon circulation and the consequential numerous convection modes (Anders and Nesbitt 2015). In the Central Massif in France, during the inflow of air from the Mediterranean Sea, frequent precipitation was observed in narrow bands with a longitude direction, and thus very little influence of orography on the amount of precipitation in the latitude direction (Cosma et al. 2002). Identifying the eastwest oriented gradient is also problematic in the Himalayas (Anders et al. 2006). Moreover, above a certain elevation threshold a.s.l., the gradient inversion mentioned, i.e. decreasing amount of precipitation despite an increase in elevation which has not been fully investigated, and is addressed by observers in the Sierra Nevada mountains in Spain (Collados-Lara et al. 2018) - can be observed. Statistical models for calculating the amount of precipitation in precipitation fields forming a regular grid are expected to solve those and other problems (Daly et al. 1994, Goovaerts 2000). These models provide more or less reliable data, but even when minor errors are achieved 
for the precipitation due to supra-regional atmospheric circulation, the errors occur for local precipitation, especially the storm precipitation (Minder et al. 2008).

This paper discusses the problem of spatial variability of precipitation amount on the microregional scale based on the measurements at sites with distance from one another even below one kilometre. Attention was drawn to the exposition of elevation research profiles in relation to the main direction of moist air masses inflow causing the precipitation. The major objective of the study was to investigate the gradient value at different terrain exposition figures. The work can be helpful in estimating the amount of precipitation in mountainous areas without a measuring network. Accurate estimation of precipitation is of utmost importance for creating all hydrological forecasts.

\section{METHODS}

The study was conducted in southern Poland, in the area of the Western Beskids and, more specifically, in the area of the Silesian Beskids and the Little Beskids (Figure 1). It covered both own measurements and analysis of the data from meteorological stations belonging to the national research institute for meteorology and hydrology - Institute of Meteorology and Water Management (IMGW).

Own measurements were grouped in two mountain valleys: the Barbara stream valley in the Silesian Beskids and the Wilkówka stream valley in the Little Beskids (Figure 1). In the longitudinal profiles of those valleys, 5 rain gauges were installed in each, from the estuary to source areas (Figure 2). In the valley of the Barbara stream (Figure $2 \mathrm{~A}$ ) with NNW exposition, rain gauges were installed at the following elevations: 480, 620, 740, 860 and $920 \mathrm{~m}$ a.s.l. The horizontal distance between the lowest and highest rain gauges was $3.5 \mathrm{~km}$. The precipitation was measured approximately every 10 days, from July 1 to November 15, 2015. The Wilkówka stream valley (Figure $2 \mathrm{~B}$ ) has the SW exposition. The rain gauges were installed at the following elevations: $485,530,640,820$ and $909 \mathrm{~m}$ a.s.l, and the horizontal length of the profile was $3 \mathrm{~km}$. The precipitation was measured approximately every 10 days from July 19 to October 18, 2015.

The IMGW data was sourced from a public database and used to calculate the precipitation gradient in the area of two mountains: Błatnia in the Silesian Beskids and Leskowiec in the Little Beskids (Figure 1). The amount of precipitation was measured at the meteorological stations located in the peak parts of the aforementioned mountains, as well as in their surroundings (Figure 3). In the Błatnia region, the following stations (Figure $3 \mathrm{C}$ ) were involved: Błatnia (907 m a.s.1.), Brenna (305 m a.s.1.), BielskoBiała (401 m a.s.1.), Szczyrk (606 m a.s.1.), Brenna Leśnica (422 $\mathrm{m}$ a.s.1.), and in the Leskowiec region (Figure $3 \mathrm{D}$ ): Leskowiec (895 $\mathrm{m}$ a.s.1.), Wadowice (272 m a.s.1.), Ślemień (458 m a.s.1.), Kocierz Moszczanicki (489 m a.s.1.). Such choice of stations enabled the analysis of data in elevation profiles with different expositions. The data from 2014-2018 was analysed. The average annual summarised precipitation values were used to calculate the precipitation gradient.

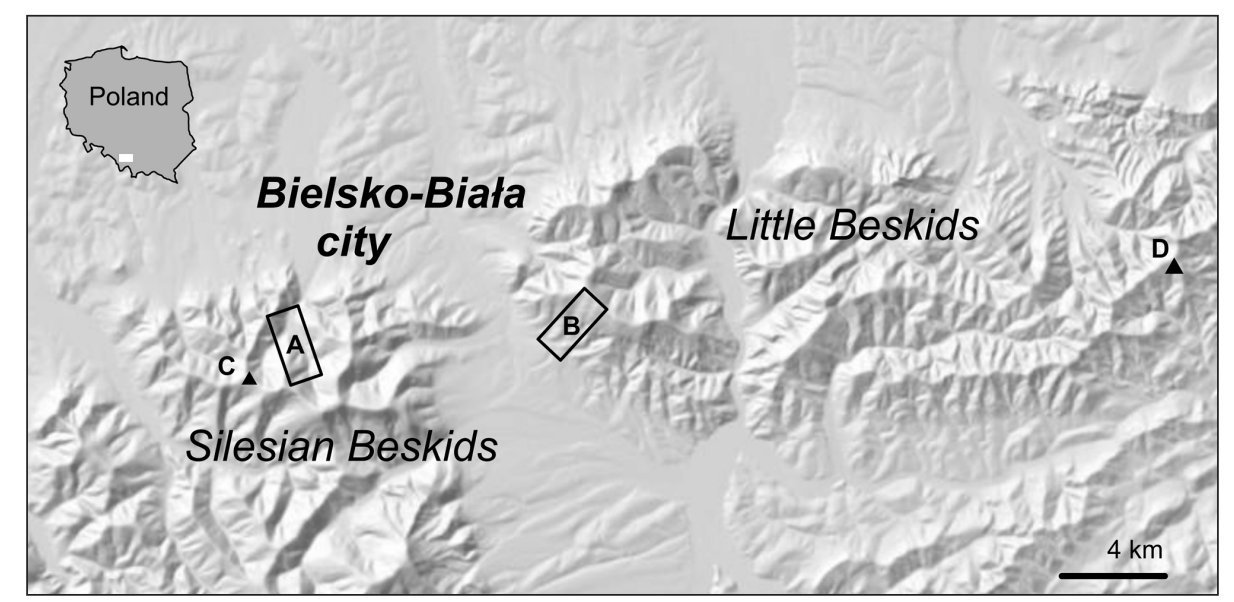

Figure 1. The region of the Silesian Beskids and the Little Beskids in the Polish Carpathians with the location of the test sites: A - the valley of the Barbara stream, B - the valley of the Wilkówka stream, C - vicinity of the Błatnia mountain, D - vicinity of the Leskowiec mountain 


\section{RESULTS AND DISCUSSION}

In the Polish Carpathians, the exposition, i.e. orientation of an inclined area to a specific cardinal direction, is crucial for shaping the atmospheric precipitation amount patterns. The occurrence of precipitation is associated with the inflow of moist air masses flowing to that region mainly from the Atlantic, from the northwest sector (Hess 1965). In general, according to Hess (1992), wet masses pile up above the west, north-west and north mountain slopes, which thus receive the highest amount of precipitation. Niedźwiedź (1981) also mentions the climatic asymmetry of the Polish Carpathians. Due to the latitudinal orientation of mountain ranges, there is an asymmetry between the northern and southern slopes; the former are definitely more humid. According to Trepińska (2002), this is related to the phenomenon of the so-called precipitation shadow, i.e. the occurrence of heavy rainfalls on the windward side of the mountains, compared to the leeward side. Those regularities should be referred to the obtained study results, while attention should also be paid to the location of the measuring stations relative to the orientation of the surrounding mountain ranges (Hess 1973).

The first test ground, the Barbara stream valley (Figure 2 A) has NNW exposition, and the mountain range in which it is located is the first range from the north side. Due to such location, moist air reaches that point unhindered, and abundant precipitation, the amount of which increases with the terrain elevation, should be expected. Studies confirmed the hypothesis. The sums of precipitation from the subsequent rain gauges (from the lowest to the highest) were as follows: $524.7 \mathrm{~mm}$; $644.7 \mathrm{~mm} ; 726.6 \mathrm{~mm} ; 889.6 \mathrm{~mm} ; 1155.0 \mathrm{~mm}$. Apparently, they increased regularly with elevation (correlation coefficient $r=0.94$ ), with the increase being the highest in the upper part of the valley. For the entire elevation profile (from rain gauge 1 to 5), the precipitation gradient was $143 \mathrm{~mm}$ per $100 \mathrm{~m}$ of the elevation. Between the adjacent rain gauges, the gradient ranged from $68.3 \mathrm{~mm}$ (between gauges 2 and 3) to $442.3 \mathrm{~mm}$ (gauges 4 and 5).

The results obtained in the Wilkówka Stream valley (Figure 2 B) did not show a regular increase in precipitation with the elevation over the entire length of the profile. That profile is oriented in the SW-NE direction, i.e. perpendicular to the incoming rain air masses. Furthermore, the valley is located on the southern side of the mountain range; thus, it is in the precipitation shadow. Under these conditions, the precipitation totals for consecutive rain gauges (from the lowest to the highest location) were: $715 \mathrm{~mm} ; 843.4 \mathrm{~mm} ; 839 \mathrm{~mm}$; $980 \mathrm{~mm} ; 843 \mathrm{~mm}$. The precipitation gradient for the entire profile of study was $30.2 \mathrm{~mm}$ per $100 \mathrm{~m}$ of elevation, whereby the greatest amount of precipitation was not found at the rain gauge with the highest location. The minimum and maximum precipitation amounts were recorded a)

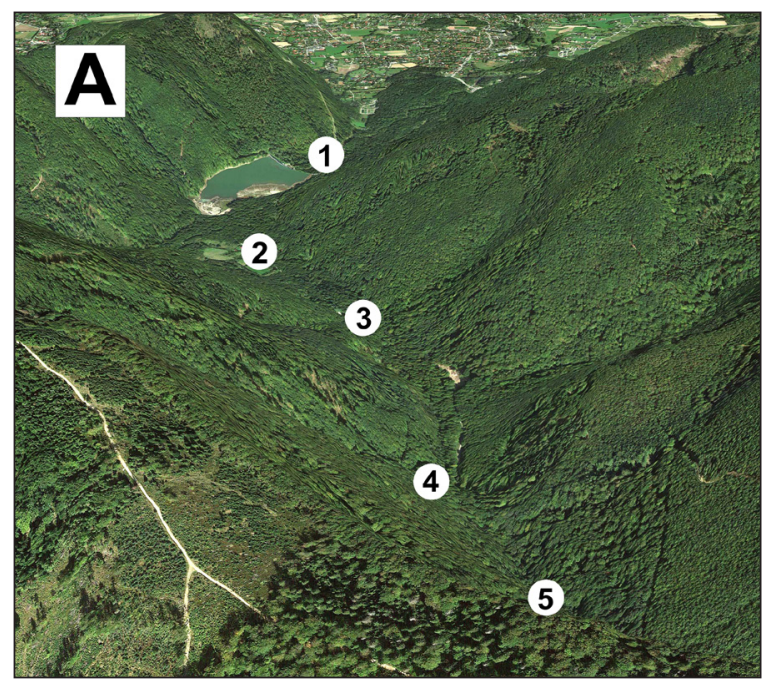

b)

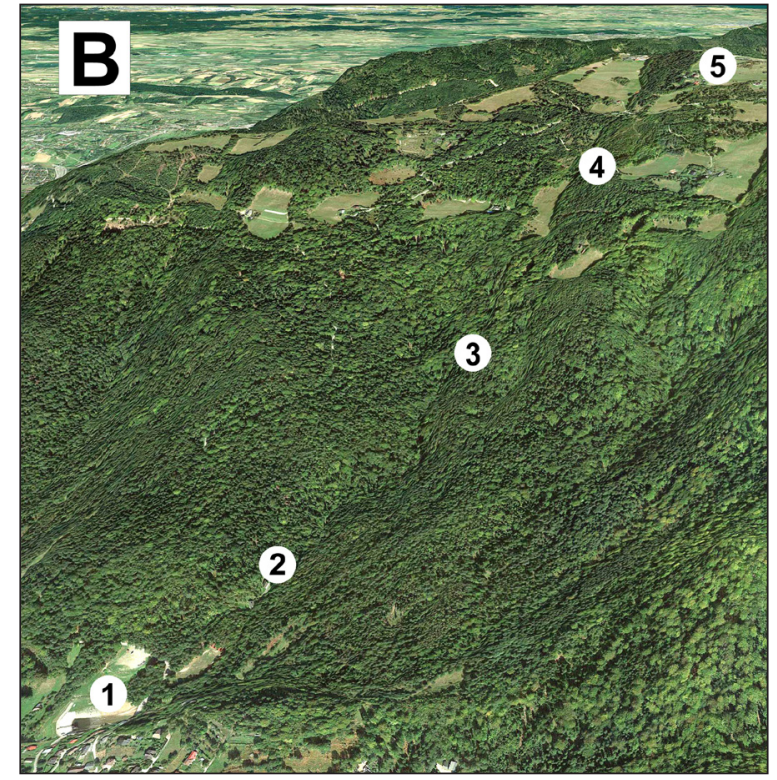

Figure 2. Location of the rain gauges in the valley of the Barbara stream (A) and the valley of the Wilkówka stream (B) 
in rain gauges 1 and 4, the gradient between those gauges was $79 \mathrm{~mm}$.

The studies in the Wilkówka stream valley point out the need to create a precipitation measurement network with a high density of rain gauges, since the calculation of the precipitation gradient solely on the basis of measurements at the foot of the mountains and in the peak areas does not give an accurate indication of the precipitation distribution across the elevation profile. This was confirmed by the analyses of the precipitation amounts at IMGW mountain and foothill meteorological stations (Figure 3). The values of the gradient between the upper and lower stations in the profiles with different exposition are given in Table 1. The gradient differed significantly; it was not present, reached values up to several dozen mm or revealed a decrease in the amount of precipitation with an increase of elevation (negative values). The gradient was most regularly shaped in the profiles running from the northern foot of the mountains, i.e. Bielsko-Biała - Błatnia and Wadowice - Leskowiec. In those cases, the increasing elevation determined the increase in the amount of precipitation. The gradient of the remaining profiles was significantly influenced by the location of the measuring stations relative to the topography. A negative gradient appeared for a specific arrangement of the surrounding mountain ranges. This was very clearly related to the Szczyrk - Błatnia profile. Although the Szczyrk station is located $301 \mathrm{~m}$ below Błatnia station, a much higher amount of precipitation was recorded there. This is due to the fact that Szczyrk is surrounded by high mountain ranges and all air masses there are elevated upwards which promotes the formation of clouds. A similar condition was found for the Błatnia Leśnica station. Attention should also be drawn to the Kocierz Moszczanicki - Leskowiec profile. Despite the elevation difference of over $400 \mathrm{~m}$, the average amount of precipitation at both stations was almost the same.

Due to the large variation in the precipitation gradient found in the arrangement of altitude profiles, an attempt was made to investigate the existence of a relationship between the amount of precipitation and the elevation above sea level in the spatial arrangement. To this end, the average annual precipitation figures at the nine analysed stations were referenced to the elevations at which they are located. The relationship with the highest correlation index took the form of a polynomial (Figure 4). It indicates an increase in the amount of precipitation along with the elevation, but only at the slopes of the Beskids. The amount of precipitation does not increase until the hilltop area, represented by the Błatnia and Leskowiec stations. At those stations, located at an elevation of about $900 \mathrm{~m}$ a.s.1, the amount of precipitation was similar to that recorded at elevations of $400-500 \mathrm{~m}$ a.s.1. This is confirmed by the aforementioned studies in the valley of the Wilkówka stream, where less precipitation was recorded in the rain gauge located in the hilltop area (on the top of Magurka Wilkowicka $909 \mathrm{~m}$ a.s.1.), than in that located at $820 \mathrm{~m}$ a.s.l. but, at the same time, identical as in the rain gauges at the elevations a)

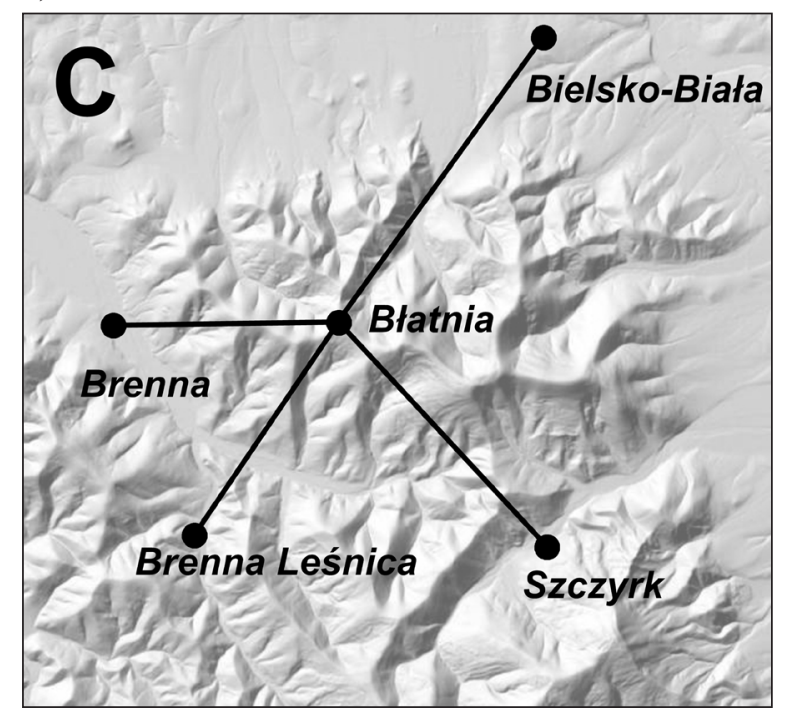

b)

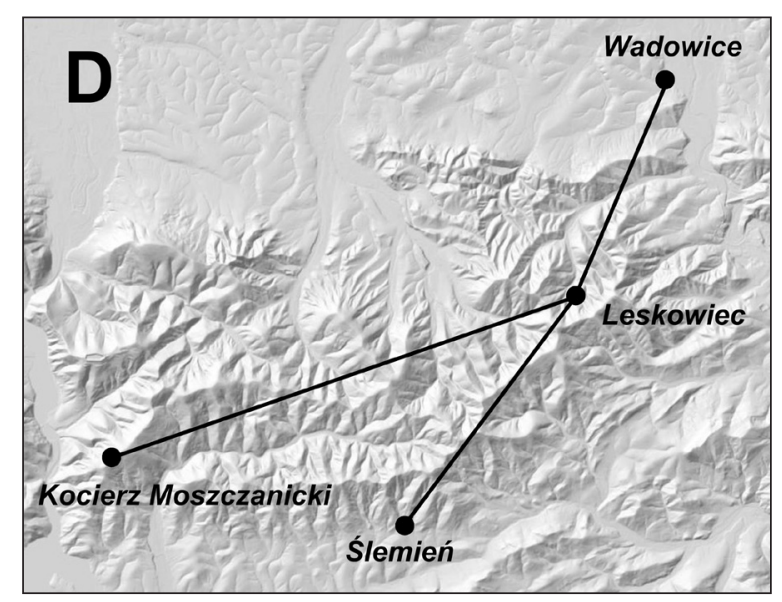

Figure 3. Location of IMGW meteorological stations in the area of the Błatnia (C) and Leskowiec (D) mountains 
Table 1. Average annual summarised precipitation (2014-2018) in the area of the Błatnia and Leskowiec mountains and precipitation gradient values

\begin{tabular}{|c|c|c|c|c|}
\hline $\begin{array}{c}\text { Top station } \\
\text { Precipitation }\end{array}$ & $\begin{array}{l}\text { Down station } \\
\text { Precipitation }\end{array}$ & Profile exposition & Altitude distance & $\begin{array}{l}\text { Precipitation gradient } \\
\text { per } 100 \mathrm{~m} \text { of elevation }\end{array}$ \\
\hline \multirow{4}{*}{$\begin{array}{c}\text { Błatnia } \\
1092.9 \mathrm{~mm}\end{array}$} & $\begin{array}{c}\text { Brenna } \\
1040.6 \mathrm{~mm}\end{array}$ & W & $602 \mathrm{~m}$ & $8.7 \mathrm{~mm}$ \\
\hline & $\begin{array}{c}\text { Bielsko-Biała } \\
966.5 \mathrm{~mm}\end{array}$ & $\mathrm{NE}$ & $506 \mathrm{~m}$ & $25.0 \mathrm{~mm}$ \\
\hline & $\begin{array}{c}\text { Szczyrk } \\
1358.9 \mathrm{~mm}\end{array}$ & SE & $301 \mathrm{~m}$ & $-88.4 \mathrm{~mm}$ \\
\hline & $\begin{array}{l}\text { Brenna L. } \\
1187.2 \mathrm{~mm}\end{array}$ & SW & $485 \mathrm{~m}$ & $-19.4 \mathrm{~mm}$ \\
\hline \multirow{3}{*}{$\begin{array}{l}\text { Leskowiec } \\
1168.9 \mathrm{~mm}\end{array}$} & $\begin{array}{l}\text { Wadowice } \\
897.5 \mathrm{~mm}\end{array}$ & NNE & $623 \mathrm{~m}$ & $43.6 \mathrm{~mm}$ \\
\hline & $\begin{array}{c}\text { Ślemień } \\
1075.7 \mathrm{~mm}\end{array}$ & SW & $437 \mathrm{~m}$ & $21.3 \mathrm{~mm}$ \\
\hline & $\begin{array}{l}\text { Kocierz M. } \\
1164.8 \mathrm{~mm}\end{array}$ & WSW & $406 \mathrm{~m}$ & $1.0 \mathrm{~mm}$ \\
\hline
\end{tabular}

of 530 and $640 \mathrm{~m}$ a.s.l. The phenomenon of a negative precipitation gradient occurring above a certain elevation is addressed in literature (Szczepanek 2003) but, as mentioned in the introduction to the article, it still raises many questions. Its occurrence in the area of study is indicated not only by data analyses, but also by field observations. Often, while hiking, the ascent to the mountain is in rain and, after reaching the top, a drizzle or fog without precipitation is encountered. The research in this area requires increasing the number of measuring stations.

A large number of measuring stations could not only help solve this issue, but also improve the calculation formulas for determining the amount of precipitation in the absence of measurements. Accuracy in determining the amount of precipitation in mountainous areas is particularly required for forecasting the flood phenomena initiated at that very point.

\section{CONCLUSION}

The studies performed demonstrate that it is quite challenging to accurately determine the amount of precipitation in mountain areas. The precipitation inflow can vary significantly even at a distance of several hundred meters from the measuring station.

The amount of precipitation on the northern slopes of the Silesian Beskids and the Little Beskids increases with the land elevation - the presence of a positive precipitation gradient is clear here. Crossing the first mountain range to the south causes a disturbance of the precipitation-elevation relationship.

Determining the precipitation gradient based on the elevation profiles with different expositions may be fundamentally flawed, since the amount of precipitation is affected by a number of environmental factors: the direction of the inflow

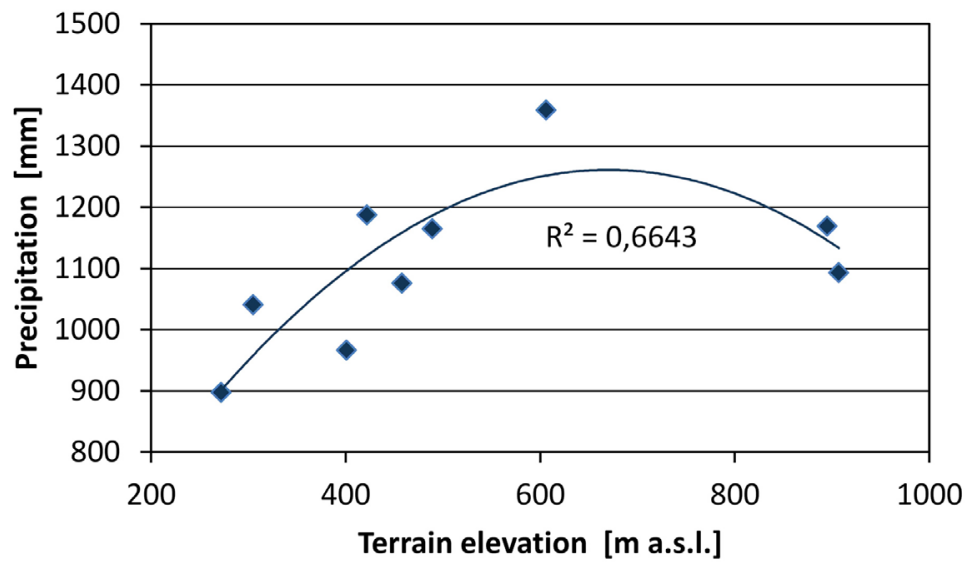

Figure 4. Relationship between the amount of precipitation and land elevation based on data from 2014-2018 for the IMGW station in the region of the Błatnia and Leskowiec mountains 
of moist air masses, orography of the land, the phenomenon of precipitation shadow, to name a few. The gradient takes up different values, also those close to zero or negative ones.

The relationship between the amount of precipitation and land elevation in a comprehensive approach is noticeable (an increase in elevation results in an increase in the amount of precipitation), with the hilltop areas receiving less precipitation than the slopes of the mountains. This proves the typically orographic nature of precipitation.

In view of the research performed, it appears reasonable to extend the studies, particularly in the catchment perspective, as a grounds for hydrological analyses.

\section{REFERENCES}

1. Anders A.M., Roe G.H., Hallet B., Montgomery D.R., Finnegan N.J., Putkonen J. 2006. Spatial patterns of precipitation and topography in the Himalaya. [In:] Willet S.D., Hovius N., Brandon M.T., Fisher D.M. (Eds.) Tectonics, Climate, and Landscape Evolution. Geological Society of America Special Papers, 398, 39-53.

2. Anders A.M., Nesbitt S.W. 2015. Altitudinal precipitation gradients in the tropics from Tropical Rainfall Measuring Mission (TRMM) precipitation radar. Journal of Hydrometeorology, 16(1), 441-448.

3. Barry R.G., Chorley R.J. 2003. Atmosphere, weather and klimate. Routledge, London.

4. Collados-Lara AJ., Pardo-Iguzquiza E., PulidoVelazquez D., Jimenez-Sanchez J. 2018. Precipitation fields in an alpine Mediterranean catchment: Inversion of precipitation gradient with elevation or undercatch of snowfall? International Journal of Climatology, 38(9), 3565-3578.

5. Cosma S., Richard E., Miniscloux F. 2002. The role of small-scale orographic features in the spatial distribution of precipitation. Quarterly Journal of the Royal Meteorological Society, 128(579), 75-92.

6. Daly C., Neilson R.P., Phillips D.L. 1994. A statistical topographic model for mapping climatological precipitation over mountainous terrain. Journal of Applied Meteorology, 33(2), 140-158.

7. Goovaerts P. 2000. Geostatistical approaches for incorporating elevation into the spatial interpolation of rainfall. Journal of Hydrology, 228(1-2), 113-129.

8. Hebda-Małocha A. 2007. Analysis of the influence of synoptic river basin's physiographic factors on precipitation spatial distribution. Czasopismo Techniczne, 2-Ś, 113-122 (in Polish).

9. Hess M. 1965. Piętra klimatyczne w polskich Karpatach Zachodnich / Climate zones in the Polish Western Carpathians. Zeszyty Naukowe UJ - Prace Geograficzne, 11, 1-255 (in Polish).

10. Hess M. (Ed.) 1973. Problemy klimatologii gór i wyżyn / Problems of climatology of mountains and highlands. Zeszyty Naukowe UJ - Prace Geograficzne, 32, 1-128 (in Polish).

11. Hess M. (Ed.) 1992. Problemy klimatologii gór i wyżyn / Problems of climatology of mountains and highlands. Zeszyty Naukowe UJ - Prace Geograficzne, 90, 1-155 (in Polish).

12. Houze R.A. (Jr.) 2012. Orographic effects on precipitating clouds. Reviews of Geophysics, 50, article number: RG1001.

13. Minder J.R., Durran D.R., Roe G.H., Anders A.M. 2008. The climatology of small-scale orographic precipitation over the Olympic Mountains: Patterns and processes. Quarterly Journal of the Royal Meteorological Society, 134(633), 817-839.

14. Niedźwiedź T. 1981. Sytuacje synoptyczne i ich wpływ na zróżnicowanie przestrzenne wybranych elementów klimatu w dorzeczu Górnej Wisły / Synoptic situations and their impact on the spatial diversity of selected climate elements in the Upper Vistula basin. Uniwersytet Jagielloński, Kraków (in Polish).

15. Szczepanek R. 2003. Czasoprzestrzenna struktura opadu atmosferycznego w zlewni górskiej. Praca doktorska / Time-space structure of atmospheric precipitation in the mountain catchment. $\mathrm{PhD}$ thesis. Politechnika Krakowska, Kraków (in Polish).

16. Trepińska J. 2002. Górskie klimaty / Mountain climates. Instytut Geografii i Gospodarki Przestrzennej Uniwersytetu Jagiellońskiego, Kraków (in Polish). 